\title{
Volume 16, Number 3
}

July 1984

\section{Journal of}
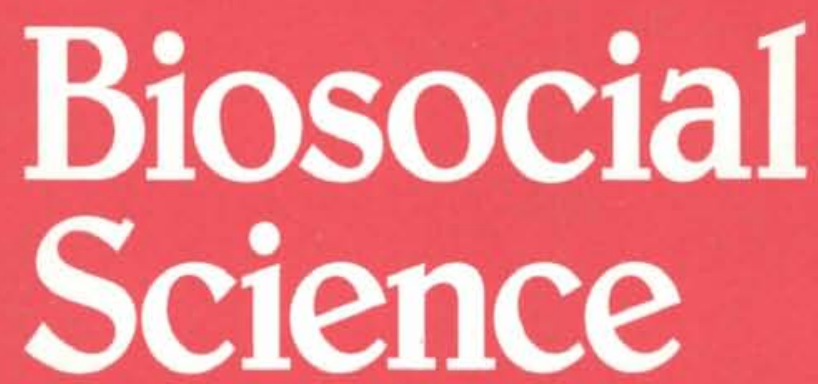

Published by The Galton Foundation

\section{Cambridge, England}




\section{JOURNAL OF BIOSOCIAL SCIENCE}

The Journal of Biosocial Science is published by the Galton Foundation and distributed by the Biochemical Society Book Depot.

Orders, payments and enquiries regarding distribution should be sent to:

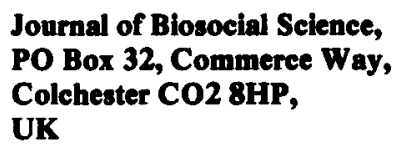

For 1984 (Volume 16) there will be four issues, published in January, April, July and October.

The subscription rates for 1984 are: Annual subscription $£ 33.00$ (US \$70.00)

Per part

$£ 9.00$ (US \$19.00)

To avoid a break in continuity subscribers are asked to place their orders, either direct or through an agent, by mid-December. Should a Standing Order be required, this should be indicated in the order instructions and an invoice will then be sent automatically in the last quarter of each year.

Limited numbers of earlier issues are available. Volumes 1-10 (1969-78, original price $£ 111.50)$ are offered to subscribers at the special price of $£ 52.00$ (US\$105.00) for the set.

Manuscripts for publication and books for review should be sent to:

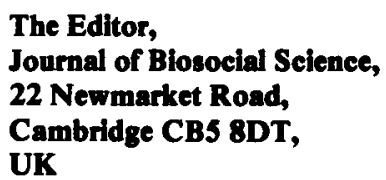

Second-class postage paid at New York, NY 10022, USA.

Postmaster. Send address corrections to: Journal of Biosocial Science, c/o Expediters of the Printed Word, 527 Madison Avenue, New York, NY 10022 USA (US mailing agent). 
Editorial Advisory Panel

\author{
Tess Adkins \\ J. A. Beardmore \\ W. Brass \\ Robert Chester
}

\author{
P. R. Cox \\ K. J. Dennis \\ Peter Diggory \\ E. Grebenik
}

\author{
G. A. Harrison \\ John Peel \\ D. M. Potts \\ J. S. Price
}

\author{
M. P. M. Richards \\ Sue Teper \\ Barbara Thompson
}

Review Editors
E. J. Clegg
G. D. Mitchell

\section{Associate Editor}

\section{A. Herbertson}

\section{Consultant}

Alan S. Parkes

\section{Notice to Contributors}

The Journal of Biosocial Science publishes original papers, reviews, lectures, proceedings and major book reviews dealing with social aspects of human biology, including reproduction and its control, gerontology, ecology, genetics and applied psychology; with biological aspects of the social sciences, including sociology, social anthropology, education and criminology; and with biosocial aspects of demography. Preference will be given to material which is clearly interdisciplinary.

Papers are considered for publication on the understanding that they have not been, and will not be, published elsewhere in whole or in part, and that, where customary, they have been approved for publication by the relevant Head of Department. The Editor is not responsible for any loss of or damage to manuscripts or illustrations and his decision on all editorial matters is final. This journal is covered by Current Contents and Biological A bstracts.

Manuscripts should be sent in duplicate to the Editor, Journal of Biosocial Science, 22 Newmarket Road, Cambridge CB5 8DT. They should be clearly typewritten, on one side of the paper only, with a $1+$ inch margin, and be double-spaced and in the English language. Spelling should follow that of the Concise Oxford Dictionary. The Editor reserves the right to make minor literary emendations in the final editing, but manuscripts will not be altered substantially without consultation with the author or marked unless the paper is thought provisionally to be acceptable. The author is responsible for the accuracy of quotations, tabular matter and references.

Manuscripts should bear the title of the paper, name of the Institution where the work was done, the present postal address of the author if different from that of the Institution, and a short running head of not more than 50 letters. Tities should be brief. A short summary should precede the text. Acknowledgments should be made in a separate section.

Diagrams must be numbered and should bear the author's name, short title of the paper and figure number on the back. Captions should be typed on a separate sheet.

Tables should be typed on separate sheets, be given Arabic numbers and be headed by adequate captions. Their approximate position in the text should be indicated by a note in the margin. They should not exceed in size the equivalent of one page of print. Weights and measurements should be given in metric units. Standard abbreviations should be used ( $\mu \mathrm{g}$, $\left.\mathrm{mg}, \mathrm{g}, \mathrm{kg} ; \mathrm{ml}, 1 ; \mathrm{mm}, \mathrm{cm}, \mathrm{m}, \mathrm{km},{ }^{\circ} \mathrm{C}, \%,<_{,}>, \mathrm{hr}, \mathrm{min}\right)$. Abbreviations should not be followed by, and initials need not be separated by, full points (e.g. FPA). Mean values should, where possible, be accompanied by standard errors or similar statistical indications of variance.

References in the text should be given in the manner that is standard in the Journal. Titles of journals should be abbreviated according to the World List of Scientific Periodicals, 4th edn (1964) and its supplements, and as also given in World Medical Periodicals. An unpublished paper should not be cited unless it is already in press.

Debate. A section headed Debate is reserved for comments on papers appearing in previous issues. Authors whose papers are involved will be given an opportunity to reply at similar length for simultaneous publication. Discussion of any particular paper will not normally be continued beyond the first comment or comments and the author's reply. The Editor's decision as to publication of comments is final. Comments, not exceeding 500 words (one printed page), should be sent to the Editor.

Proofs will be sent to contributors for minor corrections, and should be returned to the Editor within one week. Special attention should be given to the checking of tables, mathematical formulae and figures. Major alterations to the text will be accepted only at the author's expense. Overseas contributors are advised to arrange for a proof-reader in Great Britain. The date of receipt given at the end of the paper is that on which the script as published was received or agreed.

Offprints. A copy of the issue of the Journal in which the paper appears will be supplied free to the author, or, where there are two or more, to the author responsible for ordering offprints. Offprints may be purchased by ordering on the form sent out with the proofs.

C) Galton Foundation. With the exception of abstracts of no more than 300 words, no part of this publication may be reproduced or stored in a retrieval system in any form or by any means without the permission of both the Galton Foundation and the author. 


\section{JOURNAL OF BIOSOCIAL SCIENCE}

Vol. 16, No. 3

W. K. A. Agyei

H. Bantje

P. R. A. Hinde

M. Klat

A. Khudr

C. M. Langford

G. W. Lasker

D. W. Lucas

C. G. N. Mascie-Taylor

A. S. Muller

R. Niemeyer

Omondi-Odhiambo

P. S. S. Rao

B. M. Reddy

J. Richard

M. H. Sheikh

J. K. van Ginneken

A. M. Voorhoeve

R. I. Woods

F. Yusuf
Contributors

July 1984

Lecturer, Department of Macroenvironmental and Population Studies, Howard University, Washington, DC

p. 323

Associate Research Professor, Institute of Resource Assessment, University of Dar es Salaam, Tanzania

p. 375

Research Student, Department of Geography, University of Sheffield

p. 309

University Claude Bernard, Villeurbanne, France

p. 369

American University of Beirut Medical Centre, Lebanon

p. 369

Senior Lecturer in Demography, London School of Economics and Political Science

p. 399

Emeritus Professor of Anthropology and Anatomy, Wayne State University, USA

p. 301

Co-ordinator of the MA Program in Demography, Australian National University, Canberra

p. 335

Lecturer in Physical Anthropology, University of Cambridge p. 301

Professor of Tropical Health, University of Amsterdam, and Director, Department of Tropical Hygiene, Royal Tropical Institute, Amsterdam

p. 411

Research Fellow, Africa Studies Centre, Leyden University, Netherlands

p. 375

Demographer, Medical Research Centre, Department of Kenya Medical Research Institute, Nairobi

p. 411

Professor and Chief, Department of Biostatistics, Christian Medical College, Vellore, India

p. 343

Research Fellow, Anthropometry and Human Genetics Unit, Indian Statistical Institute, Calcutta

p. 385

Senior Lecturer in Biostatistics, Christian Medical College, Vellore, India

p. 343

Associate Professor, Department of Applied Psychology, University of the Punjab, Lahore, Pakistan

p. 357

Scientist, Department of Health Statistics, Netherlands Central Bureau of Statistics, Voorburg

p. 411

Medical Officer, North Yemen Project, Ministry of Health, San'a, Yemen Arab Republic

p. 411

Lecturer, Department of Geography, University of Sheffield $\quad$ p. 309

Associate Professor in Demography, Macquarie University, Sydney, Australia

p. 357 